Int. J. Morphol.,

26(4):803-808, 2008.

\title{
Anatomical Variations of the Frontal Sinus
}

\author{
Variaciones Anatómicas del Seno Frontal \\ *José Marcos Pondé; "Raimundo Nonato Andrade; *José Maldonado Via; **Patick Metzger \& **Ana Clara Teles
}

PONDÉ, J. M.; ANDRADE, R. N.; VIA, J. M.; METZGER, P. \& TELES, A. C. Anatomical variations of the frontal sinus. Int. J. Morphol., 26(4):803-808, 2008.

SUMMARY: An anatomical study of the frontal sinus in 100 macerated skulls. The study introduces an innovation on the literature by means of the measurement of the sinus's volume. All the found information in the literature attained to other aspects including the diameters of the sinus and the geometric area of the same. Objective: Evaluation of the measures of the frontal sinus frequently involved in cranial base surgeries and supraorbital craniotomies in order to help the surgical approaches that cross this anatomical route Methods: The measurement included: sagital, transverse and antero-posterior diameter acquired with a paquimeter and the volume obtained after filling the sinus with sand. Results: They are in accordance with the literature that shows the male's predominance in all measurements done.

KEY WORDS: Frontal sinus; Supraorbital craniotomy; Paranasal sinus.

\section{INTRODUCTION}

The minimally invasive surgeries have acquired a growing importance in surgical interventions in order to avoid tissue damage and reduce surgical time.

In neurosurgery, the number of publications concerning these kind of approaches has also increased (Fukushima et al., 1991; Menovsky et al., 1999; Perneczky et al., 1993; Steiger et al., 2001; Taniguchi \& Perneczky, 1997). When cranial base surgery is made in the frontal region or when the supraorbital mini-craniotomy is realized, the involvement of the frontal sinus may become troublesome. The entrance by means of the craniotomy in the frontal sinus can lead to postoperative complications as CSF leakage, bone flapp infections, besides the late consequences of meningitis and brain abscess.

The frontal sinuses are two, situated in the posterior part of the supercilliary arcs, between the external and internal faces of the frontal bone. They are seldom symmetrical; generally, there is a septum between both, which usually deviates from the midline. They point upwards beyond the middle part of the supercilious and backwards to the medial part of the orbital roof. The sinuses are divided into several recesses, which communicate with each other through incomplete bony septa. Occasionally, one or both sinuses may be absent. The prominence of supercilliary arcs does not indicate the absence, presence or size of the frontal sinus. The extension upwards beyond the frontal bone may be a small one, while the orbital part may be bigger. In some cases, a sinus may be overlapping in front of the other one. Each one opens into the corresponding medium meatus of the nose, through the ethmoidal infundibulum of the frontonasal duct, and crosses the anterior part of the ethmoidal labyrinth.

The blood supply originates from the ethmoidal and supraorbital arteries, and the venous drainage takes place at the anastomotic vein located in the supraorbital notch, binding the supraorbital and superior ophthalmic veins. The lymphatic drainage is directed towards the submandibular lymphonodi. The area is innervated by the supraorbital nerve, a branch of the frontal nerve of the first trigeminal division.

\section{MATERIAL AND METHOD}

One hundred macerated skulls were randomly assigned for evaluation after section on axial plane 1 inch above the supercilliary arcs (Fig. 1).

The measures of anteroposterior, sagital and transversal diameters were taken. The presence or absence of the

\footnotetext{
* Department of Morphology Escola Bahiana de Medicina e Saúde Pública, Brasil.

** Student of Medicine Escola Bahiana de Medicina e Saúde Pública, Brasil.
} 
metopic suture were assigned. With bone-wax, the frontonasal ducts were occluded bilaterally. A syringe with fine sand was utilized to fill completely the frontal sinus and then the amount of sand necessary to complete this was quantified, verifying the volume that left the syringe. With this measure we had the approximate volume of the sinus.

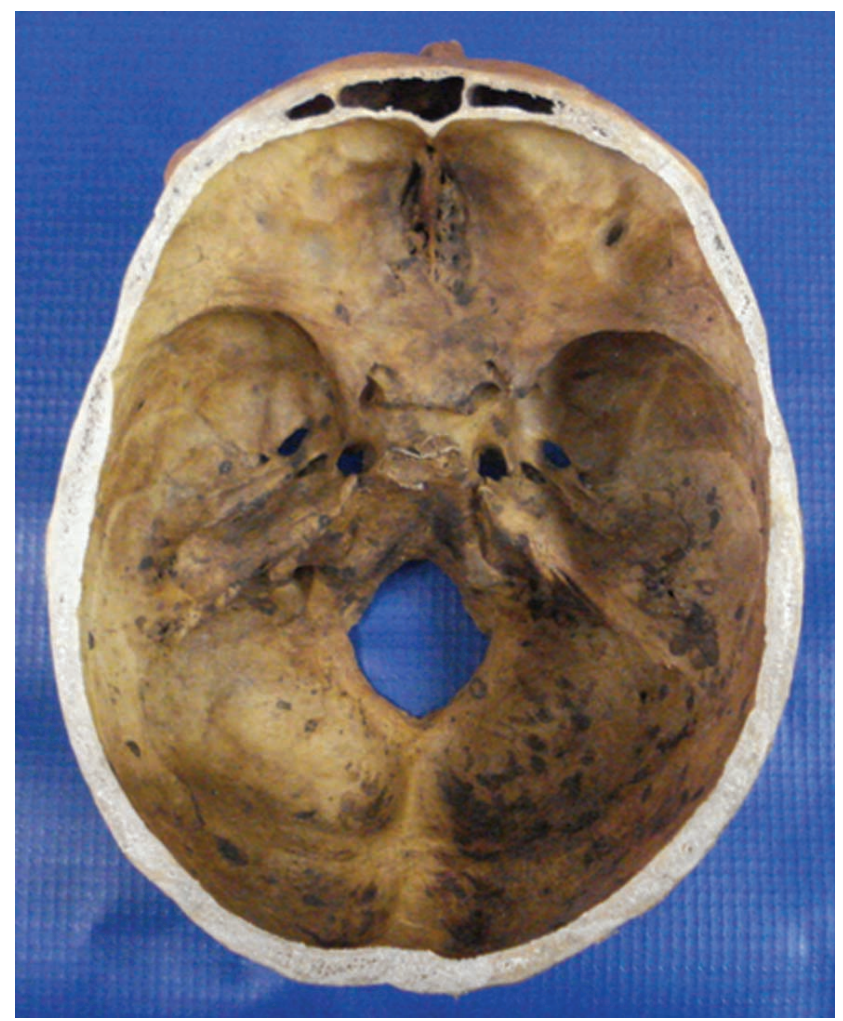

Fig. 1. Macerated skull. Section on axial plane 1 inch above the supercilliary arcs.

\section{RESULTS}

The distribution by sex is described in the tables below, followed by the location of the sinuses observed in the sample (Tables I and II). The frontal sinus was present in $75.3 \%$ of the cases and absent in $24.3 \%$. The metopic suture was absent in almost $63 \%$ (Table III) of the cases and there was no correlation between this occurrence and the frontal sinus presence.

The results obtained with measures were the following ones summarized in Table VI. The mean age was 63.55 years, with a minimal of 22 and a maximum 95 and a standard deviation of 18.20 .

The average volume of the sinuses measured with sand was 10.25 , with a minimal value of 1.1 and maximal of
38 and a standard deviation of 7.15. The mean antero-posterior diameter was $7.849 \mathrm{~mm}$, with a minimum value of 3.1 $\mathrm{mm}$ and a maximum $18 \mathrm{~mm}$ with a standard deviation of $2.91 \mathrm{~mm}$. The mean transversal diameter was $40.59 \mathrm{~mm}$, with a minimum of $4 \mathrm{~mm}$ and a maximum of $96 \mathrm{~mm}$ and of standard deviation $21.96 \mathrm{~mm}$. The median sagital diameter was $33.40 \mathrm{~mm}$, with a minimum of $11 \mathrm{~mm}$ and maximum $75 \mathrm{~mm}$.

The statistical analyses demonstrated a significant difference concerning gender and location of the sinus with predominance of the left side in males (Table IV and V).

The measures showed difference related to gender in all analyzed diameters in favor of males (Table VI). The independent sample analyses failed to demonstrate any statistical significance in taken measures but there was a trend of greatest difference in transversal diameter between genders (Table VII).

\section{DISCUSSION}

Andreas Vesalius is considered by many scholars as the father of the Anatomy. He described the frontal sinus in his famous book "Di Humani Corporis Fabrica", as a cave full of air. Falopius, one of Vesalio`s pupil, has detailed the sinus referring to their absence in newborns. Blaney (2000) reports that the frontal sinuses are anatomical structures only found in the human being and in some large African apes. Such facts draw the attention to the anatomical similarities between both species.

Schuller (1943) has verified in radiological studies that the frontal sinuses are quite bigger in males than in females, and emphasized that the presence of metopic suture is associated with absence of the frontal sinuses.

Libersa \& Faber (1957) have observed that the frontal sinus usually appear in the third year of life. Krogman (1962) reports that the frontal sinus become an extension of the nasal cavity after the second year of life and grows progressively until the age of 20 years.

Porbonikova (1974) carried out a study with 720 Xray pictures in 1 to 13 years old children by evaluating the frontal sinus growth. She observed that growth begins on the thirteenth month of age, being the same in both sexes, and goes on up to the age of 20 years when the parameters start diverging in girls who display a horizontal sinus enlargement while boys show a vertical enlargement of the sinuses. Apart this, she observed a larger growth of the left sinus when compared to the right one. 
Table I. Distribution by sex of the location of the frontal sinuses.

\begin{tabular}{lcccc}
\hline & Frequency & Percent & Valid percent & Cumulative percent \\
\hline Male & 45 & 45 & 45 & 45 \\
Female & 55 & 55 & 55 & 100 \\
\hline Total & 100 & 100 & 100 & \\
\hline
\end{tabular}

Table II. Location of the frontal sinuses.

\begin{tabular}{llcccc}
\hline & & Frequency & Percent & Valid percent & Cumulative percent \\
\hline Valid & Absent & 24 & 24.0 & 24.7 & 24.7 \\
& Left & 27 & 27.0 & 27.8 & 52.6 \\
& Right & 20 & 20.0 & 20.6 & 73.2 \\
& Central & 26 & 26.0 & 26.8 & 100.0 \\
& Total & 97 & 97.0 & 100.0 & \\
Missing & System & 3 & 3.0 & & \\
\hline Total & & 100 & 100.0 & & \\
\hline
\end{tabular}

Table III. Metopic suture.

\begin{tabular}{llcccc}
\hline & & Frequency & Percent & Valid percent & Cumulative percent \\
\hline Valid & Absent & 61 & 61.0 & 62.9 & 62.9 \\
& Present & 36 & 36.0 & 37.1 & 100.0 \\
& Total & 97 & 97.0 & 100.0 & \\
\multirow{2}{*}{ Missing } & System & 3 & 3.0 & & \\
\hline Total & & 100 & 100.0 & & \\
\hline
\end{tabular}

Table IV. Crosstabulation. Sex.

\begin{tabular}{|c|c|c|c|c|c|}
\hline & & & Situation & & Total \\
\hline & & & Left & Right & \\
\hline \multirow[t]{4}{*}{ Sex } & Male & Count & 16 & 6 & 22 \\
\hline & & $\%$ within gender & 72.7 & 27.3 & 100.0 \\
\hline & Female & Count & 11 & 14 & 25 \\
\hline & & $\%$ within gender & 44.0 & 56.0 & 100.0 \\
\hline \multirow[t]{2}{*}{ Total } & & Count & 27 & 20 & 47 \\
\hline & & $\%$ within gender & 57.4 & 42.6 & 100.0 \\
\hline
\end{tabular}

Table V. Chi-square test. a Computed only for a $2 \times 2$ table. b 0 cells $(0 \%)$ have expected count less than 5.

\begin{tabular}{lccccc}
\hline & Value & df & $\begin{array}{c}\text { Asymp. sig. } \\
\text { (2-sided) }\end{array}$ & $\begin{array}{c}\text { Exact sig. } \\
\text { (2-sided) }\end{array}$ & $\begin{array}{r}\text { Exact sig. } \\
\text { (1-sided) }\end{array}$ \\
\hline Pearson Chi-square & 3.951 & 1 & 0.047 & & \\
Continuity correction & 2.863 & 1 & 0.091 & & \\
Likelihood ratio & 4.031 & 1 & 0.045 & & 0.045 \\
Fisher's exact test & & & & 0.076 & \\
Linear-by-linear association & 3.866 & 1 & 0.049 & & \\
No of valid cases & 47 & & & & \\
\hline
\end{tabular}


Table VI. T - test

\begin{tabular}{lllccc}
\hline Group Statistics & Gender & n & Mean & Std. deviation & Std. error mean \\
\hline Volume & Male & 34 & 11.875 & 5.957 & 1.0216 \\
& Female & 39 & 10.1492 & 8.0401 & 1.2874 \\
Antero-posterior diameter & Male & 34 & 8.0265 & 2.7192 & 0.4663 \\
& Female & 39 & 7.9718 & 3.104 & 0.497 \\
Transversal diameter & Male & 34 & 44.5985 & 22.6357 & 3.882 \\
& Female & 39 & 37.9128 & 21.1621 & 3.3886 \\
Sagital diameter & Male & 34 & 36.6382 & 10.4821 & 1.7977 \\
& Female & 39 & 33.5467 & 11.7744 & 1.8854 \\
\hline
\end{tabular}

Table VII. Independent sample test

\begin{tabular}{|c|c|c|c|c|c|c|c|c|c|}
\hline & & $\begin{array}{l}\text { Levene's Test } \\
\text { for equality } \\
\text { of variances }\end{array}$ & & $\begin{array}{l}\text { t-test for } \\
\text { equality } \\
\text { of means }\end{array}$ & & & & & \\
\hline & $\mathrm{F}$ & Sig. & $\mathrm{t}$ & $\mathrm{df}$ & $\begin{array}{c}\text { Sig. } \\
\text { (2-tailed) }\end{array}$ & $\begin{array}{c}\text { Mean } \\
\text { difference }\end{array}$ & $\begin{array}{l}\text { Std. Error } \\
\text { difference }\end{array}$ & $\begin{array}{l}95 \% \text { Confidence interval } \\
\text { of the difference }\end{array}$ & \\
\hline & & & & & & & & Lower & Upper \\
\hline \multicolumn{10}{|l|}{ Vol ume } \\
\hline Equal variances & 0.69 & 0.409 & 1.029 & 71 & 0.307 & 1.7258 & 1.6771 & -1.6183 & 5.0698 \\
\hline Equal variances not & & & 1.05 & 69.288 & 0.297 & 1.7258 & 1.6435 & -1.5527 & 5.0043 \\
\hline \multicolumn{10}{|l|}{ Ant ero-posterior } \\
\hline Equalvariances & 0.74 & 0.394 & 0.079 & 71 & 0.937 & $5.47 \mathrm{E}-02$ & 0.6878 & -1.3168 & 1.4261 \\
\hline Equal variances not & & & 0.08 & 70.997 & 0.936 & $5.47 \mathrm{E}-02$ & 0.6816 & -1.3043 & 1.4137 \\
\hline \multicolumn{10}{|l|}{ Transversal diameter } \\
\hline Equal variances & 0.18 & 0.672 & 1.304 & 71 & 0.197 & 6.6857 & 5.1289 & -3.5411 & 16.912 \\
\hline Equal variances not & & & 1.297 & 68.109 & 0.199 & 6.6857 & 5.1529 & -3.5965 & 16.967 \\
\hline \multicolumn{10}{|l|}{ Sagital diameter } \\
\hline Equalvariances & 0.44 & 0.508 & 1.177 & 71 & 0.243 & 3.0916 & 2.6261 & -2.1447 & 8.3279 \\
\hline Equal variances not & & & 1.187 & 70.963 & 0.239 & 3.0916 & 2.6051 & -2.1028 & 8.286 \\
\hline
\end{tabular}

Szilvassy (1981) studied the variability of the frontal sinus in children and young people aged between 3 and 7 years, in 215 children. He observed that between the age 8 to 12 years, the growth rate of male frontal sinus is a very low one. Between the age 14 to 15 years, male frontal sinuses exceed female ones, where size is concerned, so we can conclude that a complete formation of the sinuses takes place at the age of 18 .

The measures of diameters have all been significantly higher in males than in females according the literature
(Blaney; Hanson \& Owsley, 1980; Libersa \& Faber; Pondé et al., 2003; Porbonikova; Szilvassy), though none of these authors had ever measured the antero-posterior neither the volume, only the area of the sinuses. Ponde found a significantly higher antero-posterior diameter when comparing both genders $(\mathrm{p}<0.001)$ in a study with computer tomography (Pondé et al.).

Brown et al. (1984) have found in a simple X-ray study that the sagital diameter is significantly larger in males. They have found an average of $32.6 \mathrm{~mm}$ in males against 
$26.6 \mathrm{~mm}$ in females. In a similar work, Harris et al. (1987) have found a height of $30.1 \mathrm{~mm}$ in males against $26.0 \mathrm{~mm}$ in females. Pondé et al. have found that the sagital diameters were significantly higher in males $(\mathrm{p}<0.04)$.

Porbonikova reports that females have a proportionally larger frontal sinuses than males, when compared to the sagital diameter, which is much larger in males. She justifies this finding as being due to a more homogeneous growing of frontal sinuses in females if compared with sinus growth in males. Pondé found measures of $58.3 \mathrm{~mm}$ and $46.9 \mathrm{~mm}$ in males and females respectively, but without statistical significance $(\mathrm{p}<0.10)$.

Harris et al. has found such measures as $58.3 \mathrm{~mm}$ in males and $46.9 \mathrm{~mm}$ in females. In the total sum of measures, it was possible to verify that the frontal sinuses of males showed a quite higher development than those of females $(\mathrm{p}<0.01)$ according others authors (Krogman; Menovsky et al., 1999; Phrabhakaran et al., 1999; Schuller). Pondé et al. have emphasized the antero-posterior diameter as the most important contribution for the significant increase of volume in the male's sinuses when compared with females (Pondé et al.).

What regards the absent frontal sinus, Krogman has observed its absence in 5\% adults, while Gulisano et al. (1978) observed its absence in $4.8 \%$ of the cases. We observed $24.7 \%$ of frontal sinus missing with $20.8 \%$ in males and $27.9 \%$ in females. Gulisano et al. has also observed that the left sinus tends to be larger than the right one, a fact that could be observed by Pondé et al. though they had not found any difference between the genders and within the sample itself.

PONDÉ, J. M.; ANDRADE, R. N.; VIA, J. M.; METZGER, P. \& TELES, A. C. Variaciones anatómicas del seno frontal. Int. J. Morphol., 26(4):803-808, 2008.

RESUMEN: Se presenta un estudio anatómico del seno frontal que fue realizado en 100 cráneos. El estudio introduce una novedad en la literatura, que es la medida volumétrica del seno frontal. Toda la literatura se refiere a otros aspectos, incluyendo los diámetros de los senos y su área geométrica. El objetivo del estudio fue estimar las medidas del seno frontal que con frecuencia hacen parte en las cirugías de la base del cráneo y en las craneotomías supraorbitarias, con la finalidad de facilitar las vías de acceso quirúrgico por estas regiones. Las medidas realizadas fueron: diámetro sagital, transversal y antero-posterior con un caliper, y el volumen fue obtenido llenando el seno con arena fina. Los resultados están de acuerdo con la literatura que demuestra un mayor predominio del sexo masculino en todas las medidas efectuadas.

\section{PALABRAS CLAVE: Seno frontal; Craneotomía supraorbitaria; Seno paranasal.}

\section{REFERENCES}

Blaney, S. P. Scaling properties of the frontal sinus in the African great Apes - a clue to the role of the human paranasal sinuses. Ver. Laryngol. Otol. Rhinol., 121(2):99-102, 2000.

Brown, W. A.; Molleson, T. I. \& Chinn, S. Enlargement of the frontal sinus. Ann. Hum. Biol., 11(3):221-6, 1984.

Fukushima, T.; Miyazaki, S.; Takusagawa, Y. \& Reichman, M. Unilateral interhemispheric keyhole approach for anterior cerebral artery aneurysms. Acta Neurochir., 53:427, 1991.

Gulisano, M.; Pacini, P. \& Orlandini, G. E. Frontal sinus dimensions in relation to the cranial index. Anatomoradilogic Findings. Boll. Soc. Ital. Bio. Sper., 54(1):66-9, 1978.
Hanson, C. L. \& Owsley, D. W. Frontal sinus in Eskimo populations. Am. J. Phys. Anthropol., 53(2):251-5, 1980.

Harris, A. M. P.; Wood, R. E.; Nortjé, C. J. \& Thomas, C. J. The frontal sinus: Forensic fingerprint .A pilot study. $J$. Forensic Odontostomatol., 5(1):9-15, 1987.

Krogman, W. M. The Human Skeleton in forensic medicine. Thomas, Springfield, 1962.

Libersa, C. \& Faber, M. Étude anatomo-radiologique du sinus frontal chez l'enfant. Lille Méd., 3:453-9, 1957.

Menovsky, T.; Grotenhuis, A.; Vries, J. \& Bartles, R. Endoscope-assisted supraorbital craniotomy for lesions of the interpeduncular fossa. Neurosurgery, 44:106-12, 1999. 
Perneczky, A.; Tschaitscher, M. \& Resch, K. Endoscopic anatomy for neurosurgery. Thieme, Stuttgart, 1993.

Phrabhakaran, N.; Naidu, M. \& Subramanian, K. Anatomical variability of the frontal sinus and their application in forensic identification. Clin. Anat., 12:16-9, 1999.

Pondé, J. M.; Metzger, P.; Amaral, G.; Machado, M. \& Prandini, M. Anatomic variations of the frontal sinus. Minim. Invasive Neurosurg., 46(1):29-32, 2003.

Porbonikova, S. An X-Ray investigation of the development of the frontal sinus in children. Folia Med., 16(4):21320, 1974.

Schuller, A. A note on the identification of skull X-Ray pictures of the frontal sinus. Med. J. Aust., 25(1):554-6, 1943.

Steiger, H.; Schmid-Elssaesser, R.; Stummer, W. \& Uhl, E. Transorbital keyhole approach to anterior communicating artery aneurysms. Neurosurgery, 48:34752, 2001.

Szilvassy, J. Development of the frontal sinuses. Anthropol. Anz., 39(2):138-49, 1981.

Taniguchi, M. \& Perneczky, A. Subtemporal keyhole approach to the suprasellar and petroclival region: microanatomic considerations and clinical application. Neurosurgery, 41(3):592-601, 1997.
Correspondence to:

José Marcos Pondé Department of Morphology

Escola Bahiana de Medicina e Saúde Pública BRASIL

Received: 17-03-2008

Accepted: 22-09-2008 